\title{
Implementasi Terapi Pijat Oksitosin dengan Pemberdayaan Kader pada Ibu Post Partum
}

\author{
Lutfiana Puspita Sari ${ }^{*}$, Lusinta Agustina ${ }^{2}$ \\ ${ }^{1,2}$ Jurusan Kebidanan, Poltekkes Kemenkes Surakarta \\ *Email: bidanlutfiana@gmail.com
}

\begin{abstract}
Background: Efforts to help the success of government programs related to exclusive breastfeeding must be done as early as possible from 36 weeks of gestation. Massage done in the area around the spine in pregnant women will help the secretion of the hormones oxytocin and prolactin. The oxytocin released after the massage process will stimulate labor contractions and prepare for the breastfeeding process, so it is hoped that regular stimuli given in the form of oxytocin massage will affect the production of milk produced. So it is important to introduce oxytocin massage from an early age to cadres, pregnant women, and nursing mothers. Through cadres, pregnant and lactating mothers will always be reminded to prepare for milk production from pregnancy. The purpose of this activity are to optimize the production of breastmilk in post partum mothers through mentoring health cadres. Methods: Method this study is used oxytocin massage intervention and health education. Results: Of this activity are health education and oxytocin massage intervention can increase knowledge cadre skills to help post partum mothers succeed in exclusive breastfeeding. Conclusion: Oxytocin massage can be an intervention alternative to optimize the production of breastmilk in post partum mothers.
\end{abstract}

Keywords: breastmilk production, empowerment of cadres, post partum mother, oxytocin massage

\section{PENDAHULUAN}

Air susu ibu (ASI) merupakan nutrisi alamiah terbaik bagi bayi karena mengandung kebutuhan energi dan zat yang dibutuhkan selama enam bulan pertama kehidupan bayi. Salah satu kendala yang dialami oleh ibu menyusui adalah masalah produksi ASI yang tidak lancar. Tingginya angka kegagalan ASI ekslusif di Indonesia tersebut salah satunya disumbangkan oleh ibu yang mengalami masalah dalam proses laktasi (Sitepoe, 2013).

Cara yang dapat dilakukan oleh ibu agar produksi ASI lancar ketika melahirkan salah satunya dengan pijat oksitosin. Pijat oksitosin merupakan intervensi yang dapat dilakukan untuk mengurangi kecemasan pada ibu post partum dan dapat membantu melancarkan produksi ASI sehingga dapat menyukseskan program pemerintah terkait ASI ekslusif. Patofisiologi mengapa pijat oksitosin dapat melancarkan produksi ASI yang keluar karena pemijatan ini dilakukan pada sepanjang tulang belakang (vertebrabte) sampai tulang costae kelima-keenam. Pemijatan atau rangsangan yang dilakukan pada tulang belakang, neurotransmitter merangsang medulla oblongata dan mengirim pesan ke hipothalamus di hipofise posterior untuk mengeluarkan oksitosin yang menyebabkan payudara mengeluarkan ASI.

Pemijatan ini juga akan merelaksasi ketegangan dan menghilangkan stress. Berdasarkan hasil riset, mekanisme pemijatan ini akan memberi efek bagi ibu untuk relaks dan tenang karena dengan dilakukan pemijatan akan menurunkan aktivitas hipothalamus pituitari adrenal (HPA), ketika HPA menurun maka ACTH pun akan mengalami penurunan. Hormon oksitosin dan prolaktin yang keluar setelah 
dilakukan pemijatan akan memberikan efek ketenangan pada ibu sehingga produksi ASI dapat keluar dengan lancar (Morhenn, 2012).

Berdasarkan hasil penelitian (Sari, 2017) terbukti bahwa pijat oksitosin efektif dapat mengoptimalkan produksi ASI pada ibu post partum. Besarnya manfaat/efek setelah pijat oksitosin ini dilakukan, sehingga perlu disosialisasikan kepada para kader kesehatan untuk mengimplementasikan terapi pijat oksitosin kepada ibu post partum sehingga mengurangi kecemasan ibu terhadap produksi ASI yang keluar. Kader kesehatan berperan besar dalam upaya meningkatkan kemampuan masyarakat, menolong dirinya dalam mencapai derajat kesehatan yang optimal. Kader juga berperan dalam pembinaan masyarakat dibidang kesehatan melalui kegiatan yang di lakukan posyandu.

Kader juga merupakan orang yang paling dekat dengan masyarakat dan mampu memberikan motivasi melalui pendidikan kesehatan kepada masyarakat untuk memberikan pelatihan dan motivasi kepada calon ibu menyusui sejak kehamilan agar dapat mempersiapkan sejak dini sukses asi ekslusif. Sebelum memberikan pendidikan kesehatan kepada masyarakat maka perlunya pelatihan bagi kader tersebut agar dapat memberikan informasi sesuai dengan evidence based terbaru. Berdasarkan hasil wawancara dengan bidan desa wilayah pandes, wedi, Klaten bahwa kader belum pernah terpapar oleh materi tentang pijat oksitosin dan masih banyak ibu post partum yang memberikan susu formula kepada bayinya dengan alasan asinya kurang dan tidak cukup untuk memenuhi kebutuhan bayi. Berdasarkan dari fenomena tersebut kami tertarik melakukan pengabdian masyarakat dengan tema 'Implementasi Terapi Pijat Oksitosin dengan Pemberdayaan Kader pada Ibu Post Partum di Desa Pandes, Wedi, Klaten'.

\section{TINJAUAN PUSTAKA}

ASI mengandung semua nutrisi yang dibutuhkan bayi dalam 6 bulan pertama kehidupan, seperti lemak, karbohidrat, protein, vitamin, mineral, dan air. ASI juga mengandung faktor bioaktif yang meningkatkan sistem kekebalan tubuh pada bayi prematur, melindungi terhadap berbagai penyakit infeksi, dan faktor-faktor lain yang membantu pencernaan dan penyerapan nutrisi (WHO, 2009). ASI sangat bermanfaat baik bagi ibu maupun bayi untuk jangka pendek maupun jangka panjang. Manfaat ASI bagi bayi terkait dengan efek perlindungan terhadap berbagai macam penyakit yaitu ASI mampu menurunkan risiko infeksi pencernaan, kandung kemih, saluran nafas, menurunkan risiko infeksi telinga, mencegah diare, dan risiko SIDS (suddent infant death syndrome)/sindrom kematian bayi mendadak, alergi, diabetes, haemophilus influenzae meningitis dan bahkan obesitas di masa datang (Jhaquin, 2010).

Beberapa faktor yang dapat mempengaruhi keberhasilan dalam memberikan ASI ekslusif kepada bayi, antara lain adalah faktor sosial budaya, meniru teman, tetangga atau orang terkenal yang memberikan susu formula, faktor psikologi, faktor fisik ibu, faktor bayi, faktor tenaga kesehatan serta meningkatnya promosi susu kaleng sebagai pengganti ASI. Faktor psikologi berperan penting dalam menentukan keberhasilan ASI ekslusif. Depresi yang terjadi pada ibu post partum (setelah 
melahirkan) akan memberikan risiko macetnya produksi ASI yang keluar. Depresi tersebut adalah segala perasaan yang berhubungan dengan kesedihan, kecemasan, serta perasaan tidak ada yang mau menolongnya pasca melahirkan. Hormon stres yang dialami oleh ibu akan menekan pengeluaran hormone oksitosin dan prolaktin yaitu hormon yang berpengaruh terhadap produksi ASI (Sitepoe, 2013).

Paparan stres baik berupa fisik (nyeri) maupun emosional (kecemasan) akan mengaktifkan sistem endokrin yaitu hipotalamus-hipofisis-adrenal (HPA) dan sistem saraf simpatis, sehingga meningkatkan produksi hormon stres seperti hormone kortisol, kortikotropin serta katekolamin. Berdasarkan hasil riset setelah terjadi peningkatan hormon kortisol maka akan diiringi oleh peningkatan kadar glukosa yang tinggi. Tingginya kadar hormon kortisol dan glukosa berhubungan dengan tertundanya proses pemenuhan susu pada payudara dan menyebabkan penurunan jumlah produksi ASI masing-masing payudara pada minggu pertama post partum (Coussons-Read, 2012 )(Adedinsewo, 2014).

Ada beberapa hal yang dapat dilakukan sebelum menyusui untuk merangsang reflex oksitosin menurut WHO/UNICEF, diantaranya adalah:

a. Membantu ibu secara psikologis dapat dilakukan dengan cara : membangkitkan rasa percaya dirinya, mengurangi sumber nyeri dan kecemasan ibu sebelum memerah ASI, serta membantu ibu membangun pikiran dan perasaan positif tentang bayinya.

b. Minum-minuman hangat yang menenangkan

c. Ibu dapat melakukan kompres hangat atau mandi air hangat

d. Memijat tengkuk dan punggung ibu agar rileks

e. Pijatan ringan pada payudara

f. Merangsang putting susu

g. Membantu ibu untuk relaks (Modul 40 jam Pelatihan Konseling Menyusui WHO / UNICEF).

Teknik non farmakologi yang dapat dilakukan untuk memperlancar produksi ASI salah satunya dengan Pijat oksitosin. Hormon yang sering dikaitkan dengan proses persalinan dan pengeluaran ASI adalah hormon oksitosin. Oksitosin merangsang ketenangan, menginduksi efek anti stres, menurunkan kepekaan terhadap nyeri, mengurangi peradangan, dan merangsang proses yang berkaitan dengan pertumbuhan dan penyembuhan, sehingga harapannya setelah dilakukan pijat oksitosin ibu akan mengalami ketenangan karena pada waktu proses pemijatan terjadi peningkatan hormon serotonin dan dopamin dan menurunnnya hormon norepinephrine dan kortisol sehingga hormon oksitosin akan keluar dan memberikan efek peningkatan produksi ASI (Moberg, 2013).

Berdasarkan hasil riset yang dilakukan oleh Latifses et al., (2005) pemijatan merupakan metode yang efektif dalam menurunkan tingkat kecemasan pada ibu post partum (setelah melahirkan). Berdasarkan hasil riset membuktikan bahwa pemijatan di sekitar tulang belakang dapat meningkatkan hormon noradrenalin dan ibu mencapai kondisi yang tenang. Hormon noradrenalin merupakan hormon yang dihasilkan oleh medulla dan memberikan efek ketenangan pada sistem syaraf simpatis. Ibu yang mencapai kondisi tenang merupakan salah satu faktor 
keberhasilan menyusui.

Massage (pemijatan) diperlukan untuk mencapai kondisi relaks, nyaman, tenang, dan menambah kepercayaan diri. Pemijatan mampu menurunkan emosi negatif seperti kecemasan, nyeri, stres. Pemijatan dapat meningkatkan sistim saraf parasimpatis karena dengan tekanan pada permukaan kulit dapat mengaktifkan reseptor di kulit selain itu ketika pijat oksitosin dilakukan maka hormon oksitosin akan keluar selama proses pemiijatan (Lindgren, 2012). Salah satu terapi massage yang digunakan untuk memperlancar produksi ASI adalah pijat oksitosin. Terapi pijat oksitosin merupakan salah satu teknik untuk merangsang keluarnya hormon prolaktin dan oksitosin setelah melahirkan.

\section{METODE}

Sasaran pada kegiatan pengabdian masyarakat ini adalah ibu kader yang ada di wilayah Desa Pandes, Wedi, Klaten berjumlah 40 kader kesehatan. Kegiatan Pengabmas ini dilaksanakan pada tanggal 11 April 2018 pukul 08.00-13.00 WIB. Tahapan pelaksanaan program kegiatan Pengabmas adalah sebagai berikut:

a. Penyuluhan kesehatan: Untuk meningkatkan pengetahuan tentang Teknik menyusui yang benar dan pijat oksitosin untuk meningkatkan produksi ASI. Peserta dijelaskan tentang materi pijat oksitosin dan semua responden diberikan booklet yang berisi tentang materi pijat oksitosin serta teknik menyusui dengan benar serta kiat dan sukses memperlancar produksi ASI. Booklet yang dibagikan kepada peserta, tujuannya adalah agar dapat dibaca kembali materi penyuluhan yang sudah diberikan atau mereview kembali materi yang telah disampaikan. Dengan booklet ini juga dapat lebih meningkatkan kemampuan untuk dapat memberikan penyuluhan kepada masyarakat serta dapat meningkatkan dan mendukung program pemerintah tentang ASI ekslusif dengan cara mengajarkan kepada masyarakat khususnya kepada ibu postpartum terkait pijat oksitosin

b. Terapi Pijat Oksitosin: Tim pengabmas memberikan materi dan pemutaran video terlebih dahulu sebelum mengajarkan Teknik 'Pijat Oksitosin'”. Setelah itu tim, mempraktekkan secara langsung yang diikuti secara berpasangan oleh semua peserta secara bergantian. Tim mendampingi satu persatu dan melakukan evaluasi jika ada yang masih tidak sesuai. Pijat Oksitosin ini dilakukan langkah demi langkah sesuai SOP yang sudah ada di booklet dan yang sudah dipraktekkan oleh tim pengabmas. Teknik pijat oksitosin ini efektif untuk meningkatkan produksi ASI bagi ibu post partum terutama ibu post partum pada hari 1-3. Untuk melihat kemampuan yang diajarkan peserta diminta untuk redemonstrasi Pijat Oksitosin antar teman. Peserta diajak bersama melakukan Pijat oksitosin seperti yang sudah diajarkan langkah demi langkah metode 'Pijat Oksitosin" untuk membantu meningkatkan produksi ASI. Redemonstrasi dilakukan 2 kali. Peserta diminta untuk melakukan 'Pijat Oksitosin" kepada ibu post partum terutama yang baru melahirkan untuk mengoptimalkan produksi ASI. Pijat oksitosin dilakukan minimal 2 kali sehari. Setiap kali melakukan sekitar 10-15 menit. 


\section{HASIL}

Kegiatan pengabdian masyarakat yang dilakukan di Desa Pandes, Wedi, Klaten memberikan hasil sebagai berikut :

\section{a. Pengetahuan Kader tentang Pijat Oksitosin dan Optimalisasi Produksi ASI}

Tim pengabmas melakukan pengukuran pengetahuan kader pre dan post tentang pijat oksitosin dan seputar ASI melalui questioner. Tim pengabdian masyarakat mempersiapkan pertanyaan secara terstruktur. Pre Test didapatkan hasil rata-rata responden dapat menjawab 50\% dari pertanyaan yang diberikan dengan nilai rata-rata 50. Langkah selanjutnya adalah pemberian pendidikan kesehatan beserta demonstrasi teknik pijat oksitosin. Pendidikan kesehatan, yang bertujuan untuk meningkatkan pengetahuan tentang pijat oksitosin dan konsep untuk mengoptimalkan produksi ASI. Responden yang hadir sangat bersemangat dan aktif bertanya tentang materi yang disampaikan serta antusias dalam mendemonstrasikan teknik pijat oksitosin antar teman.

Evaluasi pelatihan yang dilakukan dengan cara yang sama seperti di awal sebelum diberikan pelatihan dengan memberikan questioner dengan pertanyaan yang sama kepada peserta dan meminta responden mempraktekkan kembali teknik pijat oksitosin yang sudah diajarkan. Hasil evaluasi terjadi peningkatan, dengan rata-rata peningkatan nilai sebesar 40 poin sehingga nilai pengetahuan kader meningkat menjadi rata-rata 90. Mayoritas responden sebesar 90\% dapat menjawab pertanyaan dengan tepat, dapat menjelaskan kembali serta mempraktekkan tentang penatalaksanaan pijat oksitosin untuk mengoptimalkan produksi ASI.

\section{b. Evaluasi Pelaksanaan tentang Efektifitas Pijat Oksitosin untuk Mengoptimalkan Produksi ASI}

Evaluasi tentang Teknik pijat oksitosin terkait optimalisasi produksi ASI, ibu-ibu kader diberi tugas dan tanggung jawab 'One Kader One Client" . Sehingga 1 kader wajib mendampingi 1 ibu post partum pada hari pertama untuk diajarkan Teknik pijat oksitosin kemudian melakukan evaluasi terkait dengan produksi ASI yang dihasilkan setelah dilakukan pijat oksitosin selama 3 hari. Pendampingan kader yang dilakukan kepada ibu post partum serta efektivitas dari pijat oksitosin yang telah dilakukan dapat dilihat pada tabel berikut :

Tabel 1. Evaluasi Pelaksanaan Pijat Oksitosin Terkait dengan Produksi ASI

\begin{tabular}{lcc}
\hline Nama & $\begin{array}{c}\text { Jumlah Produksi ASI sebelum } \\
\text { dilakukan Pijat } \text { Oksitosin }\end{array}$ & $\begin{array}{c}\text { Jumlah Produksi ASI setelah } \\
\text { dilakukan Pijat Oksitosin } \\
\text { selama 3 hari }\end{array}$ \\
\hline Ny. Am & $30 \mathrm{cc}$ & $250 \mathrm{cc}$ \\
$\mathrm{Ny} \mathrm{Si}$ & $50 \mathrm{cc}$ & $300 \mathrm{cc}$ \\
$\mathrm{Ny} \mathrm{Th}$ & $40 \mathrm{cc}$ & $350 \mathrm{cc}$ \\
$\mathrm{Ny} \mathrm{Ar}$ & $100 \mathrm{cc}$ & $300 \mathrm{cc}$ \\
$\mathrm{Nny} \mathrm{Dw}$ & $60 \mathrm{cc}$ & $200 \mathrm{cc}$ \\
$\mathrm{Ny} \mathrm{Ms}$ & $50 \mathrm{cc}$ & $300 \mathrm{cc}$
\end{tabular}




\begin{tabular}{lrl}
\hline Ny Tw & $40 \mathrm{cc}$ & $350 \mathrm{cc}$ \\
Ny Hc & $80 \mathrm{cc}$ & $300 \mathrm{cc}$ \\
Ny Df & $150 \mathrm{cc}$ & $350 \mathrm{cc}$ \\
Ny Rs & $60 \mathrm{cc}$ & $250 \mathrm{cc}$ \\
\hline
\end{tabular}

Berdasarkan tabel diatas terlihat jelas setelah dilakukan selama 3 hari berturutturut pijat oksitosin Nampak terjadi perbedaan yang sifgnifikan dan produksi ASI mengalami peningkatan yang signifikan. Pijat oksitosin ini dilakukan $2 \mathrm{x}$ dalam sehari dengan durasi kira-kira 10 menit. Selain itu klien diajarkan tentang Teknik menyusui yang benar dan motivasi untuk rajin menyusui.

\section{PEMBAHASAN}

Berdasarkan hasil evaluasi menunjukkan bahwa ada perbedaan yang signifikan mengenai produksi ASI yang dihasilkan antara sebelum dan sesudah diberikan pijat oksitosin. Banyak faktor yang berperan dalam perkembangan payudara. Prolaktin dan oksitosin adalah dua hormon yang berpengaruh secara langsung terhadap produksi ASI. Frekuensi bayi dalam menyusu menyebabkan impuls sensory dari putting sampai ke otak sehingga sebagai tanggapan kelenjar pituitari dari lobus anterior mensekresi prolaktin dan lobus posterior mensekresi oksitosin. Ketika bayi menyusu, maka kadar prolaktin di dalam darah meningkat.

Kadar prolaktin paling tinggi sekitar 30 menit setelah awal menyusui sehingga efeknya adalah sebagai persiapan untuk produksi ASI untuk menyusui selanjutnya. Kadar prolactin semakin tinggi pada beberapa minggu pertama setelah melahirkan. Semakin bayi sering menyusu dan merangsang putting maka kadar prolaktin semakin tinggi sehingga ASI yang dihasilkan juga semakin banyak. Pada minggu awal pertama menyusui sangat menentukan untuk keberhasilan menyusui selanjutnya sehingga sangat penting untuk memperhatikan frekuensi bayi menyusu serta melakukan perawatan payudara agar produksi ASI lancar (WHO, 2009).

Salah satu kendala yang sering dialami oleh ibu post partum ketika ingin memberikan ASI secara dini dan ekslusif adalah ASI kurang mengalir dengan lancar pada hari-hari pertama persalinan. Hal ini disebabkan karena pada hari pertama persalinan produksi ASI masih terbatas dan aliran belum lancar yang dikaitkan dengan kurangnya stimulasi untuk prolaktin dan oksitosin yang terlibat dalam produksi ASI. Pada pasien dengan persalinan sectio caesarea sangat berbeda dengan persalinan spontan. Penggunaan obat selama operasi atau sesudahnya akan mempengaruhi kondisi ibu serta menjadi kendala dalam proses mengalirnya ASI (Varney, 2007).

Perawatan pada ibu post partum sering dilakukan hampir di setiap rumah sakit ketika ibu masih berada di rumah sakit. Hal ini bertujuan agar ibu sukses memberikan ASI ekslusif kepada bayinya. Kebijakan terkait dengan asi ekslusif sudah diberlakukan, pengadaan pelatihan dan workshop bagi tenaga kesehatan terkait dengan bagaimana supaya dapat mendukung program ASI ekslusif sering diselenggarakan, praktek IMD sudah diberlakukan di seluruh rumah sakit, termasuk memastikan produksi ASI ibu post partum cukup untuk kebutuhan bayi. Ibu harus merangsang produksi ASI yang keluar supaya tidak terjadi hambatan dalam aliran 
ASI dari ibu ke bayi dengan cara merangsang supaya reflex oksitosin keluar (Sulaeman et al., 2016).

Untuk merangsang reflex oksitosin keluar, ibu dapat melakukan sendiri ataupun dapat dibantu oleh keluarga. Jika ibu ingin melakukan sendiri maka ibu dapat memijat ringan payudaranya atau merangsang putting susu sambil memandang sang bayi jika dekat. Ibu juga dapat meminta bantuan suami/keluarga untuk melakukan pemijatan pada daerah kedua sisi tulang punggung dan bahu (pijat oksitosin). Oksitosin membuat sel-sel myoepitel di sekitar alveoli berkontraksi, sehingga ASI yang telah terkumpul di alveoli dapat mengalir dan mengisi di seluruh saluran ASI dengan lancar (WHO, 2009).

Hasil evaluasi ini didukung oleh beberapa hasil penelitian yang telah membuktikan tentang efektivitas pijat oksitosin untuk meningkatkan produksi ASI. Penelitian yang dilakukan oleh Sulaeman et al., (2016) menjelaskan bahwa rata-rata jumlah ASI yang dihasilkan pada kelompok yang diberikan intervensi pijat oksitosin adalah $9.62 \mathrm{ml}$, sedangkan kelompok yang tidak diberikan pijat oksitosin, jumlah ASI yang dihasilkan sebanyak $4.47 \mathrm{ml}$ sehingga disimpulkan intervensi pijat oksitosin efektif untuk meningkatkan produksi ASI pada ibu post partum. Penelitian yang dilakukan oleh Nurdiana et al., (2016) menyatakan bahwa ada perbedaan yang signifikan terhadap kadar hormon prolactin antara sebelum dan sesudah diberikan pijat oksitosin. Pijat oksitosin dapat digunakan untuk meningkatkan kadar hormon prolactin dan produksi ASI pada ibu post sectio secarea.

Pijat oksitosin dilakukan di sepanjang tulang belakang, dimana pada lokasi ini ibu sering merasakan tegang. Sepanjang tulang belakang terdapat titik-titik acupressure untuk memudahkan proses laktasi dan melancarkan proses aliran ASI serta syaraf di sekitar payudara yang terhubung dengan syaraf yang tersebar di sepanjang tulang belakang. Berdasarkan hasil penelitian yang telah dilakukan oleh Gorewit et al., (1985) tentang pemijatan payudara yang dilakukan pada 5 kelompok yang berbeda yaitu tanpa dilakukan pemijatan, 15 menit, 30 menit, 60 menit, dan 120 menit sebelum menyusui, ditemukan bahwa 30 menit sebelum menyusui adalah yang paling efektif untuk meningkatkan jumlah oksitosin(Kosova, 2016).

Pijat oksitosin dilakukan pada ibu post partum sebagai stimulus yang akan menyebabkan kenaikan kadar prolaktin dan oksitosin terutama pada hari-hari awal menyusui, yang pada akhirnya akan mempengaruhi produksi dan pelepasan ASI. Kelancaran terhadap produksi ASI akan mendorong ibu untuk memberikan ASI selama 6 bulan pertama kehidupan. Sehingga dapat disimpulkan bahwa pemberian stimulus berupa pemijatan pada payudara memberikan kontribusi positif untuk peningkatan jumlah produksi ASI dan membantu ibu untuk dapat memberikan makanan yang terbaik dan sehat kepada bayi sehingga akan mencetak generasi penerus yang lebih sehat dan cerdas (Kosova, 2016).

ASI diproduksi dalam alveoli, bagian awal saluran kecil air susu. Saat kehamilan saluran-saluran air susu beserta alveoli dipersiapkan untuk masa laktasi. Setelah melahirkan, laktasi dikontrol oleh dua macam reflex. Pertama, refleks produksi air susu (milk production reflex). Bila bayi mengisap putting payudara, maka akan diproduksi suatu hormon yang disebut prolaktin (prolactin), yang 
mengatur sel-sel dalam alveoli agar memproduksi air susu. Kedua, refleks mengeluarkan (let down reflex). Isapan bayi juga merangsang produksi hormon lain yang dinamakan oksitosin (oxytocin), yang membuat sel-sel otot di sekitar alveoli berkontraksi, sehingga air susu didorong menuju putting payudara. Sehingga semakin bayi mengisap, semakin banyak air susu yang dihasilkan (Prasetyono, 2012).

Ada dua macam refleks yang sangat berpengaruh terhadap produksi ASI, yaitu :

a. Refleks Prolaktin (Produksi ASI)

Setiap bayi menghisap maka ia akan merangsang ujung syaraf di sekitar payudara. Rangsangan ini disalurkan ke otak dan merangsang kelenjar hipofisis bagian depan untuk memproduksi hormon prolaktin. Prolaktin dialirkan ke pabrik ASI, merangsang sel-sel alveoli pembuat ASI untuk memproduksi ASI. Semakin banyak ASI dikeluarkan dari payudara maka semakin banyak produksi ASI, sehingga semakin sering ibu menyusui bayinya maka produksi ASI akan semakin banyak. Hormon prolaktin juga dapat menekan fungsi indung telur (ovarium) sehingga menyusui secara ekslusif akan dapat memperlambat kembalinya kesuburan dan haid, sehingga dapat digunakan sebagai KB alami untuk menjarangkan kehamilan.

b. Refleks Oksitosin (Pengaliran ASI) / (Love reflex, let down reflex)

Isapan bayi akan merangsang bagian belakang kelenjar hipofisis di otak. Kelenjar hipofisis bagian belakang akan memproduksi hormon oksitosin. Hormon oksitosin dialirkan melalui darah menuju payudara, kemudian akan merangsang otot-otot yang mengelilingi pabrik untuk berkontraksi sehingga ASI diperas keluar dari pabrik ke saluran ASI, sehingga hanya ASI yang dapat dikeluarkan oleh isapan bayi dan atau diperas ibu. Jika reflex oksitosin tidak bekerja dengan baik maka bayi tidak mendapatkan ASI yang mewadai karena ASI di saluran ASI kurang, walaupun produksi ASI dalam pabrik cukup (Roesli, 2012).

Kapasitas payudara dalam menyimpan ASI bervariasi pada masing-masing ibu hal ini berkaitan dengan lama dan frekuensi payudara disusukan kepada bayi. Kapasitas payudara dalam menyimpan ASI berkisar 300-800 ml. Kapasitas payudara tidak dapat ditentukan oleh penilaian visual. Payudara yang besar mungkin berisi jaringan adiposa yang meningkat daripada jaringan payudara. Bayi dari ibu yang memiliki kapasitas payudara dalam penyimpanan susu yang lebih kecil akan menyusui lebih sering daripada bayi dari ibu dengan kapasitas penyimpanan yang lebih besar hal ini bertujuan untuk menerima susu dalam jumlah yang sama dalam sehari. Aturan tentang jumlah dan berapa lama bayi harus menyusu harus dihindari. Sebagian besar bayi yang sehat akan menyusu antara delapan sampai dua belas kali dalam waktu dua puluh empat jam. Untuk mempertahankan produksi ASI yang cukup bagi bayi, maka dalam sehari ( 24 jam) harus ada transfer susu ke bayi selama 8-12 kali dalam sehari (State Government Victoria, 2014).

Pada 2-3 hari pertama setelah persalinan payudara mampu memproduksi ASI sebanyak 300-400 $\mathrm{ml}$ dan mulai hari kelima sebanyak 500-800 ml dalam 24 jam. Sehingga jika bayi menyusu minimal 8x sehari maka jumlah produksi ASI dalam 2-3 
hari pertama setelah persalinan dalam setiap kali menyusu adalah sekitar $50 \mathrm{ml}$. Pada hari pertama setelah persalinan produksi kolostrum yang dihasilkan dalam 24 jam adalah sekitar $50 \mathrm{ml}$. Jika bayi menyusu 8-12 kali dalam 24 jam maka setiap kali menyusui produksi ASI yang dihasilkan adalah sekitar $6 \mathrm{ml}$ (WHO, 2009).

Berdasarkan hasil penelitian yang telah dilakukan pada beberapa populasi yang berbeda tanpa memperhatikan latar belakang ras ibu ataupun status nutrisi, ratarata volume ASI yang dihasilkan dalam 24 jam sebanyak 750 gr atau sebanding dengan $835 \mathrm{ml}$. Jika Volume produksi ASI yang keluar dalam 24 jam pada 10 hari pertama post partum adalah $835 \mathrm{ml}$. Bayi menyusu sebanyak 8-12 kali dalam 24 jam. Sehingga produksi ASI yang dihasilkan setiap kali penyusuan adalah sekitar $70 \mathrm{ml}$ pada 10 hari pertama.

\section{KESIMPULAN DAN SARAN}

\subsection{Kesimpulan}

Kesimpulan dari hasil kegiatan pengabdian kepada masyarakat ini adalah pengetahuan kader kesehatan tentang Teknik pijat oksitosin untuk meningkatkan produksi ASI meningkat menjadi 90\%. Dan setelah dipraktekkan kepada ibu post partum dengan melakukan pendampingan selama 3 hari berturut-turut kepada 10 ibu post partum, rata-rata mengalami peningkatan produksi ASI $>100 \%$ pada hari ke-3 post partum.

\subsection{Saran}

Diperlukan tindak lanjut terkait dengan efektivitas Teknik pijat oksitosin agar dapat dijadikan inovasi program bagi kader untuk memberikan edukasi kepada masyarakat yang bisa dilakukan mulai saat kehamilan usia diatas 36 minggu atau pada hari 1 post partum sehingga produksi ASI akan meningkat dan suskes ASI ekslusif.

\section{UCAPAN TERIMA KASIH}

Terimakasih kami ucapkan kepada Direktur, Kepala Pusat Penelitian dan Pengabmas Poltekkes Kemenkes Surakarta, atas dana dan support untuk terselenggaranya Pengabmas ini.

\section{DAFTAR RUJUKAN}

Adedinsewo, D.A., Fleming, A.S., Steiner, M., Meaney, M.J., Girard, A.W. (2014). Maternal anxiety and breastfeeding: Findings from the MAVAN (Maternal Adversity, Vulnerability and Neurodevelopment) study. Journal of Human Lactation, 30 (1): 102-109

Coussons-Read, M.E. (2012). The Psychoneuroimmunology of Stress in Pregnancy. Current Directions in Psychological Science, 21 (5): 323-328

Jhaquin, A. (2010). Psikologi untuk kebidanan. Nuha Medika: Yogyakarta.

Kosova, F., Demirtas, Z., SeldaÏldanCalim, Sapmaz, L. (2016). The Effect on 
Lactation Of Back Massage Performed in The Early Postpartum Period. Journal of Basic and Applied Research, 2 (2): 113-118

Lindgren, L. (2012). Emotional and physiological responses to touch massage. v.3.

Moberg, K.U., Prime, D.K. (2013). Oxytocin - a system activator. Infant, 9 (6): 201206

Morhenn, V., Beavin, L.E., Zak, P.J. (2012). Massage increases oxytocin and reduces adrenocorticotropin hormone in humans. Alternative Therapies in Health and Medicine, 18 (6): 11-18

Prasetyono. (2012). Buku Pintar Asi Ekslusif; Pengenalan, Praktik dan Kemanfaatannya. Diva Press: Yogyakarta.

Roesli, U. (2012). Panduan Konseling Menyusui. Pustaka Bunda: Jakarta.

Sari, L.P., Salimo, H., Budihastuti, U.R. (2017). Optimizing the Combination of Oxytocin Massage and Hypnobreastfeeding for Breast Milk Production among Post-Partum Mothers. Journal of Maternal and Child Health,

Sitepoe. (2013). ASI Ekslusif Arti Penting Bagi Kehidupan”. PT index: Jakarta.

State Government Victoria. (2014). Promoting breastfeeding [1]

Varney, H. (2007). Buku Ajar Asuhan Kebidanan Edisi 4. EGC: Jakarta.

WHO. (2009). Infant and young child feeding 